www.jmscr.igmpublication.org

Index Copernicus Value: 79.54

ISSN (e)-2347-176x ISSN (p) 2455-0450

crossref DOI: https://dx.doi.org/10.18535/jmscr/v7i6.140

Journal Of Medical Science And Clinical Research

IGM Publication

An Official Publication of IGM Publication

\title{
To study of serum lipid profile alteration in subclinical hypothyroidism patients: A prospective case control hospital based study
}

\author{
Author \\ Dr Anil Kumar Gupta
}

Assistant Professor, Dept. of General Medicine, MSY Medical College \& Hospital, Lalpur, Meerut (U.P), India

\begin{abstract}
Background: Thyroid hormones have significant effects on the synthesis, mobilization and metabolism of lipids. Hence the present study was planned to determine lipid abnormalities in patients with subclinical hypothyroidism and its interpretation.

Material \& Methods: A total of 50 that is, 25 cases of subclinical hypothyroidism and 25 euthyroid controls were selected for the study. Demographic data such as age and sex were recorded. Lipid profile was assessed, which based on NCEP (National Cholesterol Education Program) guidelines and thyroid profile was assessed.

Results: In our study the mean age of cases was 36.54 years and in controls was 24.45 years $(p<0.001)$. BMI was statistical not significant in between groups. It was also observed that among the cases the mean TSH level was significantly high. However no significant difference was noted among cases and controls when fT3 and fT4 were compared. The significant rise was noted in cases with regard to serum cholesterol and triglycerides but no difference between cases and controls when mean HDL and LDL were compared. Conclusion: We concluded that subjects with laboratory report of hypercholesterolemia and hypertriglyceridemia should be also further examined and tested for serum thyroid hormones measurements.
\end{abstract}

Keywords: Thyroid hormones, Subclinical hypothyroidism, Lipid profile, TSH level.

\section{Introduction}

Hypothyroidism is defined as a deficiency of thyroid activity. It results from reduced secretion of total thyroxine (T4) and triiodothyronine (T3). Subclinical hypothyroidism $(\mathrm{SCH})$ can be best defined as a high serum thyroid stimulating hormone (TSH) and normal serum total/free thyroxine (T4), triiodothyronine (T3) concentrations associated with few or no symptoms/signs of hypothyroidism. It is referred to as a state of mild thyroid failure and is essentially a laboratory diagnosis. ${ }^{1,2}$ Subclinical hypothyroidism is much more common than overt hypothyroidism. ${ }^{3,4}$ Therefore, early diagnosis and treatment may prevent the onset of overt hypothyroidism and its associated effects.

In India according to a projection from various studies on thyroid disease, it has been estimated that about 42 million people in India suffer from thyroid diseases. ${ }^{5}$ Recent population-based study reported prevalence of hypothyroidism as $3.9 \%$ and prevalence of subclinical hypothyroidism was 
also high $(9.4 \%)$. In women, the prevalence was higher $11.4 \%$, when compared with men, in whom the prevalence was $6.2 \%$. The prevalence of subclinical hypothyroidism increased with age. ${ }^{5}$ Thyroid hormones have significant effects on the synthesis, mobilization and metabolism of lipids. They affect serum cholesterol mainly by altering lipoprotein metabolism. Subclinical hypothyroidism may be associated with increased risk of coronary artery disease (CAD), peripheral vascular disease, and various biochemical abnormalities including increased LDL-C levels, increased total cholesterol and serum triglyceride values. $^{6}$ It is uncertain whether subclinical hypothyroidism (increased serum TSH, normal serum T4 and T3) is also associated with hyperlipidemia. Some case-control studies, have reported increased concentration of serum total cholesterol and LDL cholesterol in subjects with subclinical hypothyroidism compared with euthyroid controls. ${ }^{7}$

Several large cross-sectional studies found no significant difference in total cholesterol or LDL$\mathrm{C}$ between subjects with subclinical hypothyroidism and euthyroidism. ${ }^{8-10}$ However, the results of lipid profile alterations in subclinical hypothyroidism are controversial in different studies; some of those showing positive correlation and prompt reversal of changes following treatment ${ }^{11,12}$ and while other refuting any correlation between the two. ${ }^{13}$ Further, there are very few Indian studies about lipid profile changes in subclinical hypothyroidism.

Hence the present study was planned to determine lipid abnormalities in patients with subclinical hypothyroidism and its interpretation.

\section{Material \& Methods}

Patients with subclinical hypothyroidism attending OPD of Department of General Medicine, MSY Medical College \& Hospital, Lalpur, Meerut. A total of 50 that is, 25 cases of subclinical hypothyroidism and 25 euthyroid controls were selected for the study.

\section{Inclusion Criteria}

- Patients with

○ Elevated TSH levels (> $5.00 \mu \mathrm{IU} / \mathrm{mL}$ )

$\circ$ Normal Free T3 (FT3) levels that is, FT3 from 1.45 to $3.48 \mathrm{pg} / \mathrm{mL}$.

○ Normal Free T4 (FT4) levels that is, FT4 from 0.7 to $1.85 \mathrm{ng} / \mathrm{mL}$.

- Patients aged above 18 years.

\section{Exclusion Criteria}

- Patients with overt hypothyroidism and on treatment with thyroxine and antithyroid drugs.

- Patients on antilipidemic drugs.

- Pregnant women and those on oral contraceptives.

- Patients with acute medical illness.

- Patients with familial hypercholesteremia.

\section{Method of collection of data}

Demographic data such as age and sex were recorded. A thorough physical examination such as anthropometry, vitals and systemic examination was conducted.

\section{Lipid profile}

Based on NCEP (National Cholesterol Education Program) guidelines ${ }^{14}$ normal values of lipid parameters were;

- Low density lipoprotein < $100 \mathrm{mg} / \mathrm{dL}$.

- High density lipoprotein;

- Female $>50 \mathrm{mg} / \mathrm{dL}$.

- Males $>40 \mathrm{mg} / \mathrm{dL}$.

- Total Cholesterol $<200 \mathrm{mg} / \mathrm{dL}$.

- Triglycerides $<150 \mathrm{mg} / \mathrm{dL}$.

\section{Thyroid profile}

The thyroid profile was assessed by withdrawing venous blood under aseptic precautions and estimation of TSH, FT3 and FT4 was done using a fully automated immunoflorescence immunoassay analyser was used to estimate TSH, FT3 and FT4. The results obtained were interpreted as below; ${ }^{15,16}$

Thyroid stimulating hormone

- Normal range -0.49 to $4.67 \mu \mathrm{IU} / \mathrm{mL}$. 
- Abnormal - < 0.49 or $>4.67 \mu \mathrm{IU} / \mathrm{mL}$. Free Triiodothyronine

- Normal range -1.45 to $3.48 \mathrm{pg} / \mathrm{mL}$.

- Abnormal - < 1.45 or $>3.48 \mathrm{pg} / \mathrm{mL}$. Free thyroxine

- Normal range -0.70 to $1.85 \mathrm{ng} / \mathrm{dL}$.

- Abnormal - < 0.7 or $>1.85 \mathrm{ng} / \mathrm{dL}$.

\section{Statistical analysis}

The continuous data was expressed as mean \pm standard deviation (SD) and the comparison was done using unpaired ' $t$ ' test. A probability value ('p' value) of less than or equal to 0.05 was considered as statistically significant.

\section{Results}

In our study the mean age of cases was 36.54 years and in controls was 24.45 years $(\mathrm{p}<0.001)$. BMI was statistical not significant in between groups (table 1)

In the present study it was observed that among the cases the mean TSH level was significantly high. However no significant difference was noted among cases and controls when fT3 and fT4 were compared (table 2).

The significant rise was noted in cases with regard to serum cholesterol and triglycerides but no difference between cases and controls when mean HDL and LDL were compared (table 3).

Table 1: Parameters in both groups

\begin{tabular}{|l|c|c|c|c|c|}
\hline \multirow{2}{*}{ Parameters } & \multicolumn{2}{|c|}{ Cases (n=25) } & \multicolumn{2}{c|}{ Controls (n=25) } & \multirow{2}{*}{ p } \\
\cline { 2 - 5 } & Mean & SD & Mean & SD & \\
\hline Age & 36.54 & 12.76 & 24.45 & 1.62 & $<0.001$ \\
\hline BMI & 20.24 & 1.34 & 21.45 & 2.76 & 0.096 \\
\hline
\end{tabular}

Table 2: Mean Thyroid level

\begin{tabular}{|c|c|c|c|c|c|c|c|}
\hline \multirow[t]{2}{*}{ Parameters } & \multicolumn{2}{|c|}{ Cases $(n=25)$} & \multicolumn{3}{|c|}{ Controls $(n=25)$} & \multirow[b]{2}{*}{ DF } & \multirow[t]{2}{*}{$\mathbf{p}$} \\
\hline & Mean & SD & Mean & SD & $\mathbf{t}$ & & \\
\hline $\mathrm{TSH}(\mu \mathrm{IU} / \mathrm{mL})$ & 7.86 & 2.41 & 2.34 & 1.09 & 15.17 & 48 & $<0.001$ \\
\hline fT3 $(\mathrm{pg} / \mathrm{mL})$ & 2.06 & 0.37 & 2.01 & 0.50 & 0.04 & 48 & 1.000 \\
\hline fT4 (ng/dL) & 1.00 & 0.26 & 1.01 & 0.32 & 0.44 & 48 & 0.646 \\
\hline
\end{tabular}

Table 3: Mean lipid profile

\begin{tabular}{|l|c|c|c|c|c|c|}
\hline \multirow{2}{*}{$\begin{array}{l}\text { Lipid } \\
\text { parameters(mg/dL) }\end{array}$} & \multicolumn{2}{|c|}{ Cases (n=25) } & \multicolumn{2}{c|}{ Controls (n=25) } & \multirow{2}{*}{ t } & \multirow{2}{*}{ P } \\
\cline { 2 - 5 } & Mean & SD & Mean & SD & t & 0.034 \\
\hline Serum cholesterol & 166.03 & 37.30 & 142.62 & 35.17 & 2.106 & 0.014 \\
\hline Triglycerides & 167.4 & 69.88 & 120.53 & 33.51 & 2.115 & 0.17 \\
\hline Low density lipoprotein & 101.45 & 40.16 & 92.11 & 21.46 & 1.331 & 0.177 \\
\hline High density lipoprotein & 40.18 & 9.66 & 38.23 & 5.66 & 1.678 & 0.084 \\
\hline
\end{tabular}

\section{Discussion}

Thyroid disorders are the most common endocrinal disorders. Thyroid diseases are among the common endocrinal disorders worldwide. The symptoms of subclinical hypothyroidism are vague and non specific.

In our study the mean age of cases was 36.54 years and in controls was 24.45 years $(p<0.001)$, which was similar to a study done at Calcutta ${ }^{17}$ where it was 38.56 years and $31.55 \pm 2.1$ years in another study done in New Delhi ${ }^{18}$ and in controls mean age was 20.46 years $(\mathrm{p}<0.001)$.
BMI was statistical not significant in between groups in our study. This finding was in sharp contrast to a study ${ }^{19}$ where mean BMI was $25.5 \mathrm{~kg} /$ $\mathrm{m}^{2}$.

In the present study it was observed that among the cases the mean TSH level was significantly high. This finding was similar to a study done in New Delhi ${ }^{18}$ where mean TSH was $7.615 \pm 0.11 \mu$ IU/mL.

No significant difference was noted among cases and controls when fT3 and fT4 were compared. Free T3 levels between cases and controls were similar. This is an expected finding because 
peripheral deiodination of T4 to T3 is unaffected in subclinical hypothyroidism. A study from Italy $^{20}$ yielded similar results.

The significant rise was noted in cases with regard to serum cholesterol and triglycerides but no difference between cases and controls when mean HDL and LDL were compared. This result was in accordance with the study conducted in Punjab ${ }^{21}$ $(181.58 \pm 35.16 \mathrm{mg} / \mathrm{dL})$ However many other studies have reported higher mean total cholesterol as compared to present study like a study done in New Delhi ${ }^{18}$ shows a mean cholesterol levels of $236.724 \pm 9.472 \mathrm{mg} / \mathrm{dL}$, similarly a study done at Gorgan ${ }^{22}$ shows a mean cholesterol of $262.66 \pm 67.94 \mathrm{mg} / \mathrm{dL}$.

\section{Conclusion}

We concluded that subjects with laboratory report of hypercholesterolemia and hypertriglyceridemia should be also further examined and tested for serum thyroid hormones measurements and particularly the evaluation of thyroid stimulating hormone (TSH) should be reassessed carefully.

\section{References}

1. Ayala A, Danese MD, Ladenson PW. When to treat mild hypothyroidism. Endocrinol Metabol Clin North Am 2000;29:399-415.

2. Cooper DS. Subclinical hypothyroidism. J Am Med Assoc 1987;258: 246-7.

3. Danese MD, Landenson PW, Meinert CL and Powe NR. Effect of thyroxine therapy on serum lipoproteins in patients with mild thyroid failure: a quantitative review of the literature. $\mathrm{J}$ Clin Endocrinol Metab 2000;85:2993-3001.

4. Tunbridge WMG, Evered DC, Hall R, Appleton D, Brewis M, Clark F, et al. The spectrum of thyroid disease in a Community: the Whickham survey. Clin Endocrinol 1977;7:481-93.

5. Unnikrishnan AG, Menon UV. Thyroid disorders in India: An epidemiological perspective. Indian $\mathbf{J}$ Endocr Metab
2011;15:78-81.

6. Bhaskaran S, Kumar H, Nair V, Unnikrishnan RV, Jayakumar C. Subclinical hypothyroidism. Indications for thyroxine therapy. Thyroid Research \& Practice 2004;1:10-4.

7. Caraccio, N., Ferrannini, E. Monzani, F. Lipoprotein profile in subclinical hypothyroidism: response to levothyroxine replacement, a randomized placebocontrolled study. J Clin Endocrinol Metabol 2002;87(4):1533-8.

8. Kanaya AM, Harris F, Volpato S, Perezstable EJ, Harris T, Bauer DC. Association between thyroid dysfunction and total cholesterol level in a older Biracial population. Arch. Intern Med 2002;162:773-9.

9. Vierhapper H, Nardi A, Grosser P, Raber W, Gessl A. Low- density lipoprotein cholesterol in subclinical hypothyroidism. Thyroid 2000; 10(11):981-4.

10. Hueston WJ, Pearson WS. Subclinical hypothyroidism and the risk of hypercholesterolemia. Ann Fam Med 2004;2:351-5.

11. Atthans BU, Staub JJ, De-Lechel R. LDL/HDL changes in subclinical hypothyroidism: possible risk factor for coronary heart disease. Clin Endocrinol 1988;28:157-63.

12. Monzani F, Caraccio N, Kozakowa M, Dardano A, Vittone F, Virdis A, et al. Effect of levothyroxine replacement on lipid profile and intima-media thickness in subclinical hypothyroidism: a doubleblind, placebo- controlled study. J Clin Endocrinol Metabol 2004;89:2099-106.

13. Danese MD, Powe NR, Sawin CT, Ladenson PW. Screening for mild thyroid failure at the periodic health examination: a decision and cost- effectiveness analysis. J Am Med Association 1996;276:285-92.

14. Expert Panel on Detection, Evaluation, and Treatment of High Blood Cholesterol in 
Adults. Executive Summary of the Third Report of The National Cholesterol Education Program (NCEP) Expert Panel on Detection, Evaluation, And Treatment of High Blood Cholesterol In Adults (Adult Treatment Panel III). JAMA 2001;285:2486-97.

15. National Committee for Clinical Laboratory Standards. Protection of Laboratory Workers from Occupationally Acquired Infections: Approved Guideline. $2^{\text {nd }}$ ed., NCCLS Document M29-A2. Wayne, PA: NCCLS; 2001.

16. Nicoloff JT, Spencer CA. Clinical review 12: The use and misuse of the sensitive thyrotropin assays. J Clin Endocrinol Metab 1990;71(3):553-8.

17. Bandyopadhyay SK, Basu AK, Pal SK, Roy P, Chakrabarti S, Pathak HS, et al. A study on dyslipidaemia in subclinical hypothyroidism. J Indian Med Assoc 2006;104(11):622-6.

18. Saini V, Yadav A, Arora S, Singh R, Bhattacharjee J. Association between different degrees of hypothyroidism and serum lipids. Internet $\mathrm{J}$ Med Update 2012;7(2):3-8.

19. Kong WM, Sheikh MH, Lumb PJ, Freedman DB, Crook M, Dore CJ, et al. A six-month randomized trial of thyroxine treatment in women with mild subclincal hypothyroidism. Am J Med 2002;112:34854.

20. Squizzato A, Romualdi E, Piantanida E, Gerdes VE, Büller HR, Tanda M, et al. Subclinical hypothyroidism and deep venous thrombosis. A pilot cross-sectional study. Thromb Haemost 2007;97(5):803-6.

21. Sing K, Sing S. Alterations in Lipid Fraction Levels in Subclinical Hypothyroidism in North Indian Population. Indian J Fundamental Applied Life Sci 2011;1(2):127-32.
22. Mansourian AR. The State of Serum Lipids Profiles in Sub-Clinical Hypothyroidism: A Review of the Literature. Pak J Biol Sci 2010;13:556- 62. 